\title{
Subalternity as displacement: Memoirs of homelessness and the struggle to be heard
}

\section{Introduction}

Lee Stringer began writing about his life while he was living in a tunnel underneath Grand Central Station in New York City. Late one afternoon he was cleaning his pipe with an old pencil despite having nothing to smoke. "It dawns on me that it's a pencil," he writes. "Pretty soon I forget all about the hustling and getting a hit. I'm scribbling like a maniac; heart pumping, adrenaline rushing, hands trembling. I'm so excited I almost crap on myself. It's just like taking a hit. Before I know it, I have a whole story" (Stringer, 1998: 15). This first essay paved the way for Grand Central Winter, a book that went on to become one of the most widely distributed memoirs of homelessness. Stringer attests to the relentless silencing he faced during the twelve years he lived without housing. This experience of being silenced emerges as one of the most prominent recurring themes across the entire genre of homelessness memoirs, offering important insight into the politics of subalternity and representation.

This essay examines contemporary memoirs of homelessness in the United States and United Kingdom through a close reading of ten memoirs that speak most directly to questions of representation. In addition to describing subaltern spatial imaginaries, the memoirists cited here critique the unequal landscape of knowledge itself. Many recount efforts to make themselves heard through blog posts, letters, journalism, or spoken words, only to be repeatedly displaced by publishers, media outlets, textual repositories, and experts who act as gatekeepers. These insights enable deeper understanding of the real-world practices through which epistemic inequality is produced and, as I show in this paper, they suggest a powerful contribution to the study of subalternity in geography. While "the subaltern" is perhaps most often understood as a symbol of that which is beyond empirical reconstruction, I argue that subalternity is not simply an 
unknowable mark of discursive erasure, but a profoundly material process through which institutions of knowledge displace the voices of marginalized thinkers. In building this argument, I draw together several debates in geography and subaltern studies, including discussions of the scope and meaning of the concept of the subaltern, analyses of urban displacement in geography, and work that examines the epistemic politics of homelessness.

The study of subalternity is an enormous area of inquiry that encompasses historical and geopolitical theories of the development of capitalism and colonialism. For the purposes of this paper, I remain focused on the literature that examines subalternity as a representational category. While theories of subalternity are less often engaged to examine European or North American contexts (Byrd and Rothberg 2011), I aim to provincialize these locations as sites of epistemic power. Rather than the origin of academic theory, the US and UK instead become sites through which I apply theory that first emerged out of analysis of the history and politics of South Asia, as this body of work speaks most directly to the epistemic condition of those without housing. In the section below, I engage insights from subaltern studies to think through the representational politics of homelessness in the US and UK. Taking a geographic approach to Spivak's seminal essay "Can the subaltern speak?" I frame subalternity as epistemic displacement and argue that housed society's refusal to listen to homeless voices is itself an active force that produces the displaced location of subalternity. In the final section, I engage directly with the writings of homeless and formerly homeless memoirists to highlight the everyday practices and institutions through which subaltern voices are displaced.

\section{Subalternity, homelessness, and the refusal to listen}


Popular representations of homelessness in the US and UK often perpetuate ideologies of blame and victimization, such that unhoused people are either condemned or reduced to the status of victims in need of assistance. In each instance, it is housed society who holds the epistemic authority, while its own failures remain largely unexamined. In media representations, discourses of homeless mental illness and addiction predominate (Hodgetts et al., 2005; Renedo and Jovchelovitch, 2007; Schneider et al., 2010). Academic research also engages in medical and psychiatric approaches that classify unhoused people according to their deficits. Blasi (1994) found that the vast majority of scholarly articles on homelessness appear in medical and psychiatric journals, with only $5 \%$ published in journals on housing or political economy. In this way, the structural problems that lead to housing displacement are reduced to isolated and anomalous case studies to be solved by therapy or coercion.

In geography, a range of scholarship has sought to develop methods that reverse the objectifying lens often taken in studies of homelessness (May 2000; Cloke et al., 2001; Klodawsky, et al. 2002; Lancione, 2017). Such an effort requires framing homelessness as central, rather than exceptional, to examine how it sheds light on housed society (Schneider 2012; Farrugia and Gerrard 2016). Rather than an object of analysis, homelessness becomes a location from which social criticism emerges. Such framings align with the postcolonial project that seeks to "decenter the center" of knowledge so that traditionally marginalized locations become the starting point from which theorizing begins (Narayan and Harding, 2000). As I argue in this section, such efforts also bring up crucial discussions around the politics of subalternity.

The study of subalternity in geography remains deeply empirical. As Legg (2016) argues, post-structural critiques of representation should not overshadow the important work of empirical investigation into conditions of subalternity. Featherstone (2013) argues for the 
importance of subaltern modes of cosmopolitanism, pushing back against notions of subaltern groups as bounded in place. The growing field of subaltern geopolitics challenges the geopolitical gaze that examines the postcolonial world from the outside, and instead seeks to look back at power from within subaltern locations (Sharp 2011). Jazeel (2011) shows how academic knowledge is rooted in spatially uneven research cultures in which the "West" is positioned as the site of theory, and the rest of the world as a field site through which theory is revised. In resisting this unevenness, geographers have examined a range of subaltern geographical imaginations (Jazeel and Legg, 2019a; 2019b; Sircar 2020). Building on this work, I bring a geographic approach to the representational critique that emerged out of the field of subaltern studies, which often frames the subaltern as a "non-subject located in a (non)place" (de Jong and Mascat 2016: 718). This essay attempts to resituate subalternity by moving away from a negative discursive framing towards the more geographic concept of epistemic displacement.

Theories of subalternity trace their origins to Gramsci's understanding of knowledge as a tool of class power. While early Marxist thinkers imagined that abysmal conditions of the working classes would inevitably lead to anti-capitalist revolution, Gramsci $(1971 ; 1991)$ painted a more complex picture of the revolutionary sentiment of subordinated groups in European history. In seeking to explain the gap between the material interests of the working class and its political aspirations, he argued that elite society maintains cultural hegemony to support its power. Professional intellectuals—scientists, writers, and priests, for example — control the apparatus of knowledge production and represent the interests of elite groups. The subaltern, which Gramsci defined broadly as including all who are socially subordinated, often come to agree with ideologies that justify systemic oppression, such that their own material interests remain unspoken. Gramsci argued that the struggle for equality thus depends on the imperative 
to develop methods for fostering and analyzing subaltern resistance (Green, 2002). Organic intellectuals, as figures distinct from the established intelligentsia, are well positioned to take on this task.

Building on these ideas, subaltern studies scholars have sought to retrieve traces of subaltern resistance from the historical record of imperialism. In analyzing peasant uprisings in colonial India, the Subaltern Studies Collective sought to develop an understanding of "subaltern consciousness." Guha (1982; 1983), one of the most influential thinkers in subaltern studies, argued that subaltern consciousness can be understood by reading the colonial archive against the grain to identify its distortions. Just as scholarly cultures in the US and UK often frame homeless voices as empirical data to support experts, Guha saw that colonial history treats the peasant rebel as "an empirical person" rather than a conscious subject of his or her own history (1983: 46). Yet attempts to recover subaltern voices have been subject to multiple critiques. In discussing their work with the radical Prisons Information Group that collected and disseminated written testimonies of prisoners, Foucault and Deleuze (1977) argued that elite intellectuals should make room for oppressed people to speak for themselves. In this view, the role of intellectuals is not only to speak, but to struggle against those systems of power that deny others the opportunity to represent themselves. More broadly, the refusal to represent oppressed groups altogether has become a popular response for those who view such representations as inevitably unethical (Varadharajan, 1995).

Yet the refusal to speak presents a series of challenges. For Alcoff (1991), it risks abandoning the political responsibility to speak out against oppression. Ideological privilegetime, money, access, and training - is useful precisely in its ability to expose how systems of knowledge support oppression. For geographers, challenging spatially uneven knowledge 
cultures involves taking on the difficult task of representation. Nagar (2002) advocates a politics that resists scholarly cultures in which only academics are cited. She argues that to cite other kinds of texts is to subvert elite forms of knowledge production. Jazeel (2011) argues for the importance of reading texts unfamiliar to hegemonic academic theory in ways that honor their difference. Through such practices, knowledge can open new possibilities, instead of repetitions, and highlight the erasures embedded in dominant epistemologies. To eschew the task of representation is to suggest that subaltern expressions are not themselves insights that can be built upon and critiqued by others (Varadharajan 1995). Many influential thinkers have written from conditions of extreme deprivation, as with Gramsci who wrote from a prison cell, subject to censorship. Yet precisely because Gramsci has been so widely interpreted, no single interpretation can stand in for his work or silence his voice. From this perspective, challenging subalternity does not involve refusing to represent the subaltern, but instead proliferating a wealth of representations to ensure that no single voice comes to speak for subaltern thought.

Yet in a highly influential intervention in subaltern studies, Spivak (1988) took the critique of representation one step further to frame subalternity as a kind of absolute historical erasure. She highlighted the example of widows in colonial India who self-immolated on their husbands' funeral pyres to argue that between patriarchal and imperial representations of their actions - "she wanted to die" versus "she needed to be saved by white men" - their voices are erased entirely. In this view, it is nigh on impossible to retrieve the widow's voice, as any notion of her is a distorted product of the colonial or patriarchal imagination. The subaltern is always framed as irrevocably other by the elite intellectual who takes on the task of representation. In critiquing both speaking for the subaltern and refusing to speak, Spivak turned instead to deconstruction, arguing that subalternity pushes intellectuals to work always harder to 
deconstruct elite representations and recover oppressed narratives, even and especially when we believe we have created space to more transparently represent subaltern voices. These insights have dramatically reshaped the field of subaltern studies, which turned from examining the subaltern as an actual group to understanding subalternity as a category of representation (Acosta 2014).

With this critique in mind, it remains possible for academics to work towards responsible representation by remaining sensitive to the ways in which they ideologically construct the subaltern (Jazeel 2014). Perhaps most importantly, this involves challenging the paternalistic notion that subjugated people have a clearer understanding of oppression (Acosta, 2014). In reading the theoretical contributions of unhoused writers, I do not suggest that homelessness is a pure location upon which to ground oppositional knowledge. Indeed, many memoirs reiterate representations of self-blame or aspire to conservative visions of private property ownership. Rather than critiquing these discourses, I instead read memoirs of homelessness to identify those that build critical social theory by disputing common sense notions and hegemonic doctrines (see REDACTED 2019 for a deeper discussion of the genre itself and my method of analysis). Through building upon the ideas, logics, and conclusions of these theorists, and placing them in conversation with academic ideas, I hope to critique the erasure of subaltern voices without framing the subaltern as a uniform group. This work involves a series of editorial choices, highlighting the degree to which my representation is the result of my own standpoint, inflected as it is with my biases as a middle-class white American, academic, and critical geographer. Yet the work also identifies a series of crucial themes that emerged across a genre of often ignored texts and invites readers to turn to the original sources themselves for further insight. In this way, it urges a politics of listening to subaltern voices. 
Subalternity is often framed in relation to the politics of listening (see Peres, 1994; Craft, 1997; Sommer, 1999). While Spivak's example of self-immolation crucially illustrates that some voices are entirely lost to history, its discursive critique risks obscuring the widow's struggle to be heard, such that her voice becomes defined only by its absence. As a counterpoint to Spivak's metaphor, the embodied condition of "locked-in syndrome" reveals the centrality of listening, as it represents perhaps the most extreme limit on human expression. Many who experience total physical paralysis succeed in expressing themselves using whatever bodily function remains, as with Jean-Dominique Bauby, who wrote The Diving Bell and the Butterfly using only his left eyelid. The success of his communication depended upon the immediate presence of a sensitive listener.

From this understanding, listening is not simply the passive absence of speech, but is an active, constitutive process that itself determines the parameters of subalternity. Subalternity can thus be understood as a relationship between speaker and listener, rather than an analytical category outside of the realm of possible agency (Coronil, 1994). As with any expression, subaltern speech is open to multiple interpretations, and its meaning lies somewhere in the interplay between speaker and listener. The broader question of society's failure to listen to subaltern voices involves structures of knowledge dissemination. A focus on listening, rather than the absence of speech, places the representational refusal of elite society at the center of critique to more directly challenge unequal structures of representation. Indeed, in her later writings, Spivak revisited her understanding of subalternity to call for "structures that allow subaltern resistance to be located and heard" (2005: 483). Moving away from deconstruction, this intervention echoes Gramsci's understanding of intellectual production as deeply imbricated in material practice. 
In advocating for structures through which to amplify subaltern voices, important questions arise about the nature of historical memory and textuality. Most people struggling to survive outside of formal housing do not have the resources to write, let alone publish, their stories. Morris et al. (2017) recount the tremendous difficulty faced by working class writers in simply finding the time and space required to engage in their craft. For these reasons, the majority of homelessness memoirs are self-published e-books, and very few authors were able to secure publication with established presses. As Lisa Gray-Garcia $(2006,181)$ writes in her memoir, "I did not have the paper, I did not have a computer and further, like all low income and homeless folks I did not even have the privilege of an organized life, knowing what I would be doing from one moment to the next." Cash Carraway similarly writes, "It's hard to find the strength to keep speaking up when you have no money, no resources, when you're living in a condemned building" (2020: 226). Yet at the same time, the written word remains crucial to the work of historical preservation. To address this problem, the Latin American Subaltern Studies Group (1993) looked beyond textual forms to analyze and promote oral forms of history. In the US and UK, oral historians sought to record the oral histories of unhoused people, a project I analyze in depth elsewhere (REDACTED, 2018). Memoirs of homelessness are themselves often rooted in oral forms, recalling the interventions of anti-colonial testimonios that engage coauthorship between speakers and writers (Beverly, 1993). Ron Casanova and Tina S., both cited here, co-authored their memoirs with interlocuters who recorded their oral histories. While the interventions of oral history and testimonio do not solve the problem of orality as fundamentally linked to subalternity, they offer greater possibilities for subaltern expressions to be heard and provide a collective record of voices that are otherwise displaced. 
As I show in the section below, memoirs of homelessness reveal that the social refusal to listen to subjugated voices is not simply a passive exclusion but involves the active removal of certain speakers from public debate. While the subject of displacement has been central to scholarly analyses of gentrification and housing (Marcuse, 1986; Smith, 1996; Stabrowsky, 2014), it is also a process intrinsic to collective memory and belonging. In turn, representational modes of displacement are not simply discursive, but fundamentally linked to actual, material practices of displacement throughout history (Escobar, 2003). Memoirs of homelessness shed light on this link, as they emerge from the everyday, material reality of geographic displacement while also speaking to the politics of representation. Memoirists are not simply reflecting on their location outside of formal housing or normative domesticity, but on the unstable geography of being continually displaced. While geographers often frame homelessness as exclusion from property relations (see Blomley, 2006), life narratives reveal that it also entails the more active and constitutive process of repeated and ongoing displacement, as memoirists describe not only being kept out of spaces, but kicked out of spaces over and over again (REDACTED, 2018). In speaking from the location of displacement, such memoirs inhabit a view with no fixed position, in contrast to the godlike view from everywhere claimed in universalizing theory. This shifting, continually displaced perspective captures the qualities of subalternity as an always elusive location. As Spivak writes in a reflection on the politics of eviction, "the category of the 'homeless', everywhere, fills the place of the earlier definition of the subaltern” (2000: 38).

Finally, a focus on subalternity in the Global North reveals how imperialism unfolds today in the heart of the former empire. In geography, a growing body of scholarship analyzes homelessness through theories of empire and postcoloniality (see Peters and Robillard 2009; Christensen 2013; Schmidt and Robaina 2017; Rusenko 2020). I build on this work elsewhere 
(see REDACTED, 2018) to argue that homelessness in metropole cities can be understood as a postcolonial condition, as racialized patterns of eviction and incarceration are linked to the imperial geographies of forced displacement and containment in ways that disrupt hard boundaries between Global North and South. In the US, black and indigenous people, respectively, remain nearly seven and fifteen times more likely than whites to become homeless (NCH, 2009). In the UK, non-nationals experience higher rates of homelessness as a result of xenophobic immigration policy (Fitzpatrick et al., 2018). In both countries, homeownership and its associated cultures of domesticity have long been central to national belonging, such that losing one's home often entails being displaced from history. While fewer memoirs of homelessness represent the UK context relative to the US, both literatures reveal strikingly similar dynamics. In the following section, I analyze these memoirs together as a body of social theory that highlights everyday practices of epistemic displacement.

\section{Displaced Voices and the Struggle to Be Heard}

In large part, Lee Stringer's Grand Central Winter examines his efforts to represent himself to society through multiple venues - in the courts, newspapers, on television, and in personal interactions. Yet each time he speaks, Stringer writes, his voice is removed from public debate. For a period, he worked as a vendor for Street News, New York City's non-profit street newspaper which employed homeless writers and vendors. He describes one occasion on which a popular daytime talk show contacted Street News to recruit three vendors for a segment about homelessness. For Stringer, it was an unusual opportunity to have an audience. He writes, "Determined that by two o'clock I be the supremely informed homeless sage of daytime TV, I pull out our clip files and dive into them" (1998: 124). Yet when he ultimately appeared onstage 
with two other vendors, it became clear that their presence was fodder for an inflammatory

discussion of homeless mental illness. The host did not speak to them at all, other than to turn to the man next to Stringer and ask why he had not put on a clean shirt. Stringer writes:

We're sitting on the set like so much useless baggage, packed, but no place to go, me thumbing through a handful of crib notes, poised to put fact and figure behind my every sterling observation. Each time [the host] turns toward the set, I try my best to look bright and eager. But he never calls on me. (1998: 128)

Instead, the host spent the remainder of the show interviewing a clinical psychiatrist about his "bona fides" and his opinion of people "at risk." At the end of the show, Stringer writes:

[An assistant] quickly hustles us out of the building as if we all have communicable diseases. I devote my money to enough recreational self-destruction to put the whole experience - and subsequent thoughts on the futility of being a party to the mass-media mill - firmly out of my mind. When the show actually airs, I don't even bother watching it. (1998: 129)

Such televised coverage of homelessness is not unusual. In televised reports on homelessness in the UK, commentary of experts, officials, charity workers, and celebrities takes up $68 \%$ of overall interview material. When unhoused people are interviewed, they are most often limited to discussing personal stories to be explained by experts (Hodgetts et al., 2005).

After working as a vendor, Stringer began his career as a writer and editor for Street News. In an interview, he described the great pleasure of having an independent platform through which to make himself heard without the intermediary of domiciled experts. "That was an amazing thing, to be on the streets and not be heard as 'Joe Homeless' but just be able to have a place where I can just riff from my own mind. ... It was a wonderful forum for me" (Film Archives, 2013). Stringer describes a lengthy investigation he conducted into a property developer that masqueraded as a homeless shelter to solicit donations. He spent countless hours writing a report for Street News connecting the scandal to larger problems in homelessness management. Yet the story was ignored by the press. He writes, "In the heat of the moment I 
even imagine that the Post or the News might pick up the story up and that Street News might at last be put on the map as a real newspaper. But the story raises not a whisper" (Stringer, 1998:

101). Stringer sought to improve the journalism at Street News and grow its distribution, yet his vision was made impossible. He writes:

I enjoy working with words. That part of the job delivers a certain satisfaction. But as for any of my work making a real difference in the larger scheme of things, as for it having any impact on the growing public resentment toward homeless people, for example, I have had to climb down from my high horse. There are just too many fierce and strident voices out there these days ... and they all seem to speak louder than me. (1998: 87)

As Torck (2001) argues, street newspapers, despite their stated goal of amplifying homeless voices, often present limited horizons for doing so, as they are looked upon as charitable projects rather than journalistic sources.

The disregard of Stringer's reporting is part of a wider pattern of inequality embedded in print news media. The New York Times and other widely distributed US newspapers are largely owned, published, and edited by elites, who dominate public discourse on homelessness and poverty (Blasi, 1994). Notions of expertise further limit homeless self-representation. In journalistic methodologies, for example, primary sources must come from professional political and intellectual institutions, precluding the citation of unhoused people as experts on their own lives (Schneider, 2012). In Canada's most prominent newspapers, domiciled experts take up more than $70 \%$ of quoted material in articles on homelessness, while unhoused people are quoted less than $20 \%$ of the time (Schneider et al., 2010). This, in turn, shapes the narratives that get formulated. In particular, journalistic accounts often construct the deeply political message that homeless voices do not matter to society.

Memoirs of homelessness further reveal that the process of becoming subaltern is fundamentally linked to political economies of knowledge circulation and distribution. David 
Wojnarowicz, a celebrated photographer and gay rights activist who died of AIDS in 1992, wrote a memoir describing his experiences of living on the streets as a teenager. He critiques hegemonic social messages about poverty and homelessness, and attributes to them to the unique ability of media conglomerates to circulate thousands of copies of newspapers across the nation. He writes:

If you look at newspapers you rarely see a representation of anything you believe to be the world you inhabit. ... My gestures of communication have less of a reverberation ... because of the amount of copies the newspaper owner can circulate among the population coast to coast. ... [Yet] I can speak with photographs about many different things that the newspaper owner is afraid to address because of agenda or political pressure, or because of the power of advertiser dollars. (Wojnarowicz, 1991: 143)

Wojnarowicz highlights not only the unequal dissemination of voices, but the underlying political economic factors that contribute to the prominence of certain stories over others. While established newspapers have wide distribution, they are also subject to limitations regarding the kinds of knowledge they can promote, as the need to produce marketable publications trumps any imperative to challenge classist and racist standards of expertise (Blasi, 1994).

Even when memoirists describe gaining a platform through which to make themselves heard, the message often becomes distorted. Writer Cash Carraway spent the better part of a decade moving between precarious rental flats, friends' houses, and hostels in London, along with her daughter. She wrote her memoir, Skint Estate, using computers in a public library. On one occasion, while staying at a domestic violence shelter in London, the roof of her building collapsed. Residents, forced to sleep in the collapsed building without electricity, launched a social media campaign under the handle @ RefugeWomen that gained the attention of multiple newspapers, including The Guardian. Carraway writes, "Our message is simple and clear-this is what happens to working-class women under austerity" (2020: 220). Yet when residents met with journalists, they were asked to tell another story: "They don't want to hear our political 
message. ... They're here to create poverty porn from abused women. They keep asking us about the kind of violence we had endured. How many times were we raped? How many bruises did we have?" (2020: 222-223). Ultimately Carraway's political campaign against UK austerity was erased from the newspaper coverage, which instead focused on individual stories of abuse.

Carraway writes:

I want to talk to you about what this government has done, what this government is doing. This government has abused me more than any man could. The ceiling has crashed down - in the safehouse - because of government cuts. ... But they don't quote me on that. ... They wouldn't let us share our stories on the impact of government cuts. That would mean giving us a voice. (2020: 224)

While the platform of social media enabled@RefugeWomen to briefly make their voices heard, newspaper coverage ultimately displaced the story they wanted to tell.

Carraway further attests to the ways in which she was required to change her writing in order to make herself heard. For years, she worked low-paid, zero hour contract positions to support her daughter. While writing for small online magazines, she was often required to perform what she describes as "poverty porn," an overwrought disclosure of her everyday struggles designed as clickbait to attract online readers. She writes about one assignment, "I know full well what kind of article this is going to be but I'm in no position to decline; this isn't worthy journalism written to evoke empathy nor is it a dispatch from the underclass rejecting objectivity and providing a soundbite from the under-represented" (2020: 270). Carraway describes how, in writing about her experiences as a single mother on benefits, she was exposed over and over again to online abuse, which ultimately culminated in a campaign calling for the cancellation of her book deal. She reflects on her fears about publishing her memoir. "Can I make my voice heard? What if all of this throws me even deeper into precarity and ridicule? 
These are the questions I ask myself every day. And I'm terrified of the answers. That's why women like me don't speak up" (2020: 327).

Even something as basic as intonation can influence whether and how a voice gets heard. Many memoirists describe changing their accents — often adopting "white voice" —in order to be taken seriously by potential landlords, employers, or social workers. "Underneath my common accent," Carraway writes, "is a woman who writes stuff. I hadn't stopped writing the entire time I was working these less-than-minimum-wage-jobs" (2020: 287). Yet her voice was subject to constant critique for her refusal to "mimic the voices of those in power" (2020:335). She writes:

I wasn't the 'right person' to be discussing working-class issues - deemed too aggressive for not using 'nice language'. Acceptable middle-class language. Tone policing being the first defence for those in a position of privilege, a successful technique used to silence oppressed voices as we start to rise. (2020: 335-336)

Carraway echoes Spivak's insight that the subaltern is often called upon to speak in another voice or testify on behalf of some dominant story. In the UK, shelters often use resident testimonies to solicit funding, such that people without housing are heard only insofar as they relate stories of being saved by charitable outreach (Renedo and Jovchelovitch, 2007). Just to receive assistance, many who reside in shelters are asked to articulate hegemonic visions of homelessness as deviance and internalize discourses of self-blame (Lyon-Callo, 1999). As Carraway writes, even when her voice was included, she was limited to anecdotes deemed palatable and appropriate, either a kind of pitiable "poverty porn" or a mimicry of middle-class discourse. Any sign of anger or revolt in her voice was immediately rejected.

As unhoused people are so deeply othered by housed society in the US and UK, cultural alienation itself can make communication impossible. In 1988, John Healy published The Grass Arena, a haunting memoir that has since been widely acknowledged as a literary masterpiece. 
Growing up poor and Irish in London, Healy describes experiencing domestic abuse at home as well as anti-migrant violence in the streets. For more than a decade during the 1970 s, he lived in between prison cells and public parks, severely addicted to alcohol, subject to brutality in police custody and in prisons. When he was ultimately offered a spot in a recovery clinic in the country, he was profoundly alienated by the kindness of its middle-class staff. He writes, "I felt alone... I had only my aggression to relate with. If I couldn't use that, I couldn't communicate" (Healy, 2008:143). Almost a decade later when he reentered the world of housed society, Healy experienced a familiar dislocation:

It wasn't just the money and education, more the personality and feelings. Mine were hyped up and geared to attacking and warding off threats, so even the most innocent question startled me. ... They had all the time in the world to say 'hello' and repeat your name. No mumbling out of the side of the mouth here! ... I didn't talk about anything. There didn't seem to be any kind of hook to hang our stuff together with. Over the next few weeks I started to talk less freely. Thinking before speaking replaced what little spontaneity I previously had. (Healy, 2008: 246-247)

Healy's insight reveals how communication depends on shared cultural norms and experiences, such that alienation and trauma can make it impossible to speak to non-subaltern groups. For Healy, representational displacement happened in intimate and unseen ways, in which speech became foreclosed before it could ever be spoken.

The world of publishing, so alien to the experience of subalternity, often reaffirms this displacement. Ultimately Healy was able to make himself heard in the form of his memoir. In an interview, he described what prompted him to write:

I was doing gardening jobs for some middle-class people in Highgate, just cutting the grass and so on, when one of the women said, 'You should be a writer.' I laughed, but she said, 'Seriously, you should write your story.' 'But I don't know how to write,' I said. She told me I should just write the way I talked. Hearing a rich person say that somehow made me feel as if it would be safe. Before that it felt as if I didn't have permission, that only the middle class were allowed to write. I thought I would test it, so I started writing four pages a night, and after nine months, I had a book. (O'Connell, 2003) 
Yet Healy eventually wound up in a battle with his publisher, who allowed his memoir to go out of print. He writes:

There were no copies of my book around, even though lots of people wanted to buy it. [The publisher] had ordered a really small print run, and when I tackled them about it, we had a bit of a row. Of course, they denied it, but the fact remained that no one could get the book. It's my theory that they didn't want a working-class guy to become a premier author and the next thing I knew, they had put me out of print. ... It was a bit of a shock to realise you're good at writing but not to be able to publish. I didn't know where to go. No one is going to suddenly say, 'You're great, we're going to accept you into the bosom of the intellectuals.' That's not going to happen unless you start speaking in a phoney way. (O’Connell, 2003)

In reflecting on the publication of his book, Healy argues that the ultimate failure of his writing career "was basically all about class. I was a stranger in their midst, uneducated" (Sheridan, 2011).

Beyond media institutions and publishers, memoirists attest to the ways in which social services displaced their voices. Lars Eighner began writing his memoir while living in an abandoned bar in Texas, using a computer he salvaged from a dumpster. Travels with Lizbeth describes his experience of camping for years in cities across the US southwest alongside his dog Lizbeth. He argues that to maintain government funding, service agencies sought to categorize him as addicted or mentally ill. Although he told them that his homelessness was the result of economic factors, his explanation was ignored.

My interview with the social worker made it clear that only three explanations of homelessness could be considered: drug addiction, alcoholism, and psychiatric disorder. The more successful I was in ruling out one of these explanations, the more certain the others would become. Professional people like to believe this, they like to believe that no misfortune could cause them to lose their own privileged places. They like to believe that homelessness is the fault of the homeless - that the homeless have special flaws not common to the human condition. (2013: 156-157)

Eighner highlights how social service discourses create "the homeless" as a construct marked by addiction or illness, which further erases the possibility for self-representation. The more he 
resisted claims that he was drug-addicted or mentally ill, the more staff became convinced he was. Ultimately, they forced him to undergo HIV testing and psychiatric evaluation. Many memoirists also highlight the ways in which their critiques of homelessness management were rejected outright. As Pat McDonough writes in her memoir, "As a consultant, I expect my recommendations to be given consideration. As a Street Person, even simple suggestions are viewed as complaining and ungratefulness" (1996: 209).

In addition to being condescended to by professionals, people without housing are often denied political forms of representation. Voting, a primary method through which to speak to the state, is often impossible for those with no address. Across the US, registering to vote typically requires proof of residence, such that as few as one in ten unhoused people are able to vote (Biron, 2020). Eighner describes his inability to vote as one the most disempowering aspects of homelessness. He writes, "One of the things that bothers me most about being homeless is being disenfranchised. ... Tinhorn oligarchies do not fear the poor, but the United States does. I had always registered and voted when I had an address" (2013: 249). Stringer describes electoral politics more broadly as a flawed system of representation. He writes, "Without some instrument for expressing our collective hopes for society, we seem to be at a loss. So the governmentflawed social mechanism that it is - nonetheless tries to do what it can and, yes, the results are far from satisfactory" (Stringer, 1998: 184). In highlighting the need for an "instrument for expressing collective hopes," Stringer critiques democratic systems based on jurisdictional majorities, and echoes instead Spivak's call for infrastructures through which subaltern voices can be heard.

Memoirists also critique the ways in which political advocates can work to displace homeless voices. In the US, advocacy groups have been influential in shaping mainstream 
discourses on homelessness, often highlighting homelessness as a solvable problem distinct from capitalist inequality (Blasi 1994). Such messaging often clashes with homeless-led activist organizations. In the late 80s, unhoused people in cities across the US formed the National Union of the Homeless. At its largest, the union included twenty local chapters and 15,000 members. In 1989, several hundred homeless activists walked a 400-mile "Exodus March" to attend a housing protest in Washington, DC and secure a meeting with then-head of HUD, Jack Kemp. Ron Casanova, who co-organized the march, describes in his memoir how Kemp entirely displaced the union's agenda. "[Kemp] said something along the lines of 'you have to learn the language. When immigrants come to the United States, they know that they have to speak English. Well, you're in Washington now'" (Casanova, 1996: 189). In turning the union away, Kemp agreed to negotiate instead with what Casanova describes as "establishment homelessness organizations." Yet Casanova argues that such organizations themselves continually fail to represent grassroots homeless movements, and instead seek to use unhoused people to solicit funding. "The advocates used that march to say to the media, 'see, we are helping the homeless people, the homeless accept us as their leaders...' That's why I hate the word 'advocate.' That's why we call advocates 'poverty pimps"” (Casanova, 1996, 190).

Like Casanova, Lisa Gray-Garcia was similarly involved in grassroots homeless-led activism. Her memoir, Criminal of Poverty, documents her years of homelessness in California. She writes that although she had "no formal education or experience," she became an "organic intellectual" through her advocacy work. Ultimately, she founded POOR Magazine, a publication dedicated to disseminating poor people's scholarship. Through this project, she writes, she began to connect racialized inequality within the US to the global structures of imperialism. 
I begin to re-evaluate everything. Every media message, every implied judgment of what I should be and should have been. ... That because I was a 6th grade "drop out" who had struggled through poverty I could not be considered an expert in anything. That my voice was irrelevant. For the first time I began to recognize the larger context of my mother's and my impossible life, seeing us against the backdrop of a global poverty struggle. How the criminalizing effects of poverty reach across borders and oceans. How in many ways my family shares a struggle with poor families in Mexico, Africa and India. (2006: 196)

Gray-Garcia argues for the importance of building political consciousness among people in similar situations, writing, "I also know that like me, these folks needed a new way of seeing their own situation... More often than not they didn't value their own experience and scholarship" (2006: 196). She further calls for a new notion of expertise.

The one thing this poverty scholar must teach you is to re-think your notions of scholarship itself. Who is considered a great scholar? How is scholarship attained? How is greatness honored? And with what tools do we assess this canon? ... [Poverty] scholarship has a new canon, with new designations for greatness. Survival itself, through extreme poverty and crisis, houselessness, racism, disability, and welfare, to name a few, are what you need to qualify for poverty scholarship. (Gray-Garcia, 2007: 61)

In challenging scholarly norms of authority, Gray-Garcia highlights the epistemic displacements embedded in academic institutions and hegemonic understandings of expertise.

Beyond displacement perpetuated by institutions, housed society at large often disregards homeless voices in everyday life. On city streets, housed people often wear blinders when they encounter those who are visibly homeless (Kawash, 1998). This refusal intersects with racialized ways of seeing. In Grand Central Winter, Stringer describes witnessing the shooting of a black man on a housing estate. "A few seconds later a pair of housing cops walk out the door. They seem so bored and matter-of-fact, loping along, you'd think they were on their way to lunch. No need to rush. Just another dead nigger" (Stringer, 1998: 134-135). Stringer describes spending the remainder of the day in terror at his own vulnerability, not only unprotected by the police but targeted for police brutality because of his race. He writes that he only became visible when he was a target of arrest or ridicule. "Like Ellison's Invisible Man, we had receded into that part of 
the landscape that refused to support the American Dream. And which few are wont to see. Nonpeople in a no-man's void" (Stringer, 1998: 54). In referencing Ellison's novel, Stringer recalls Ellison's framing of racism as the refusal to see people in their full humanity (Jarenski, 2010). Such forced invisibility is bound up with racist regimes of knowledge that determine not only whose voice is heard, but whose presence is even acknowledged to begin with. In the US in particular, anti-homeless politics is deeply inflected with racist portrayals of "deserving" versus "underserving" homelessness (Willse, 2015). As a black man panhandling in New York City, Stringer argues that his words landed on people's ears not as language, but as the background din of urban life. He writes that passers-by "seem to regard the hustling homeless as part of the landscape-live slice-of-life displays in a hodgepodge urban theme park. Their 'spare some change?' incantations and the chime of coins ringing in their cups are part of the street's discordant music" (Stringer, 1998: 166). Tina S., who like Stringer lived in the tunnels underneath New York City, writes in her memoir that as a white panhandler she made better earnings. "I had a lot of advantages. Not only was I young and cute compared to most of the other panhandlers, I was also white. Commuters, at least the white ones, always saw white panhandlers easier than they saw the black ones" (Tina S., 2000: 88).

This racialized invisibility once again recalls Spivak's concept of subalternity as a kind of irrevocable absence. Homeless invisibility is further reinforced by the fact that people without housing are shockingly vulnerable to early death (NHCHC, 2006). As in Spivak's example of the self-immolated widow, it is the moment of death at which a person's voice is utterly lost to history. As Li (2009) argues, following Spivak's concept of the subaltern, death is a necessary precursor to subalternity, as the foreclosure of self-representation becomes final and irreversible. In his memoir, Nick Flynn (2004: 203) writes about the spot on the sidewalk where his father 
lived in Boston for years, "My father stands in this room, an invisible man in an invisible room in the invisible city." For Flynn, all homeless residents of Boston constituted an invisible city unto themselves, a parallel society entirely ignored. As Flynn struggled with his own precarious housing, he witnessed his father's death on the streets. He describes his memoir as encompassing his father's tragically unwritten story:

No one would find the thread that would lead to the particular stories he tells. Only his voice does that, the air moving through him, vibrating out as words. What is the word made of but breath, breath the stuff of Life? ... If I could hold my father in my hands, bring him under the light— - his stories are all there, each story is inside him. ... The only book ever written about or by him, as far as I can tell, is the book in your hands. (2004: 321-322)

In this sense, the subject of the homeless author always includes others who will never make their own voices heard. Memoirs of homelessness reveal that the stories of those who die are not lost entirely if they are listened to by others. Testified to by an author who bears witness, they can be known beyond a single, vanishing instant to create a lasting impression in the public imagination. This is precisely the effort that Spivak (1988) undertook in her essay "Can the subaltern speak?" which concludes with an account of the suicide of Bhuvaneswari Bhaduri, a woman assumed to have been motivated by an illicit affair who was actually involved in the armed struggle against British imperialism and hanged herself for political reasons. In challenging imperial and patriarchal narratives ascribed to Bhaduri's death, Spivak points to the possibility for recovering the voice of the ultimate subaltern: the self-immolated woman.

Memoirs of homelessness, over and over again, make claims to listen to and represent the lives of others who died before them. Lee Stringer, while working at Street News, developed an advice column called Ask Homey. He writes, "Homey was the quintessential homeless person, and he responded to readers' questions about the streets and the people who lived on them" (1998: 181). Through the tongue-in-cheek pseudonym "Homey," Stringer personifies the 
experience of homelessness and suggests that it lends him authority to bear witness. In the preface to his memoir, he explicitly frames himself as representing a larger marginalized collective. He writes, "The grand exploits of the high-and-mightiest—headlining the news as they had-were well documented and since have been amply dissected. But for the low and the lost, less is understood about their sprees of abandon. I was among them. This, in part, is our story" (1998: 9). In referring to himself in the plural and writing that his memoir is part of a collective story, Stringer consciously contributes his voice to a larger canon of shared voices. As Gilmore (2001) argues, autobiography is a kind of cultural labor that produces a permanent memorial to the notion of personhood. In claiming the right to speak as a representative person, memoirists not only claim belonging in a broader social collective, but also the right to represent that group's social needs and interests, precisely the work Gramsci envisioned as central to ending subalternity. In this way, memoirs of homelessness push back against the notion of subalternity as absolute silence, calling attention instead to the work of listening in challenging housed society's representational refusals.

Writing about the self can also foster connections that that present the possibility for collective self-representation. Wojnarowicz (1991: 156) describes how the process of writing and creating visual art helped him connect to the experiences of others who were similarly situated. "Making things was like leaving historical records of my existence behind.... That object or writing acts as a magnet and draws others with a similar frame of reference out of silence or invisibility." Ron Casanova similarly elaborates on the importance of building collective knowledge and power. "As long as homeless and impoverished people keep themselves isolated, we're in a dilemma. But when we reach out, contact, and embrace people who are struggling for the same dignity, we all gain — in resources, in ideas, in strength" (1996: 244). These insights 
suggest that the subaltern is also a subject who listens, and that listening to each other can help those who are subaltern to combat their own epistemic displacement. The call for collective selfrepresentation further advances the political imperative at the heart of subaltern studies and moves beyond the critique of society's failure to listen to imagine a future in which no voice is entirely displaced.

\section{Conclusion}

The displacement of homeless voices has profound implications for the kinds of knowledge produced about housing and homelessness. The struggle to be heard is not simply about agency, but about the kinds of knowledge that gain currency in society and the implications of elite hegemony. As with the uneven global geographies of knowledge, the voices of those fully ensconced in the comforts of housing have come to predominate understandings of housing precarity and displacement. Just as imperialism produces colonial categories, knowledge institutions in the US and UK carve out "the homeless" as a homogenous and debilitated population. Housed society's predominant understanding of homelessness - inflected as it is with blame, stigma and pity —often supports systems that dehumanize unhoused people and obscure the problems of housed society. This, in turn, supports larger political efforts to remove unhoused people from public spaces and enable exploitation in the housing market. The practice of disseminating homeless voices is thus essential not only to creating a more equal landscape of representation, but to challenging housing displacement itself.

While representation is inherently fraught, the genre of homelessness memoirs suggests that challenging subalternity involves creating conditions that enable more, not fewer, representations of subaltern voices. The memoirists cited here frame epistemic inequality as a 
structural problem in which certain voices are systematically removed from public discourse. They critique journalists, experts, and advocates not for representing the oppressed subject, but for displacing homeless speakers altogether. In the US and UK, newspapers, journals, televised media, and welfare institutions, rooted in structures of profit, routinely displace the ideas of those who are outside the world of propertied citizenship. By focusing on the dynamics that stand in the way of subaltern expression, memoirs of homelessness show that challenging subalternity involves not only listening to subaltern voices, but disseminating subaltern scholarship, journalism, and expertise to the degree that society can no longer refuse to listen.

The need for subaltern geographies has never been greater. More and more, experts are consulted to craft the messages and policies that shape the lives of marginalized groups, often without attempting to account for the insights of those who have the most at stake in the conversation. In addition to recovering subaltern voices, it is crucial to better understand the processes through which subalternity is produced in the first place. In this paper, I have shown how writers attesting to their experiences of homelessness in the US highlight a new and profoundly geographic understanding of subalternity as produced through everyday acts of displacement. For geographers and subaltern scholars, this insight offers several paths forward. First, it calls attention to how subalternity is continually reproduced in small, tangible ways over the course of a lifetime. In this view, subalternity is not a purely discursive or static erasure, but a shifting set of practices embedded in hegemonic knowledge institutions and ideologies. Second, this insight shows how the politics of homelessness and displacement are profoundly epistemic, highlighting the connections between material and ideological modes of oppression. Lastly, and perhaps most importantly for intellectuals and academics, it moves beyond simply critiquing flawed representations of the subaltern to challenging society's failed capacity to listen. This new 
understanding suggests a need for more robust, plentiful, and creative practices of listening and representation, such that no single voice can stand in for another and no story is left entirely unheard.

\section{Bibliography}

Acosta A (2014) Thresholds of Illiteracy: Theory, Latin America, and the Crisis of Resistance. Oxford: Oxford University Press.

Alcoff L (1991) The problem of speaking for others. Cultural Critique 20: 5-32.

Blasi G (1994) “And we are not seen": Ideological and political barriers to understanding homelessness. The American Behavioral Scientist 37(4): 563-586.

Beverly J (1993) Against Literature. Minneapolis: University of Minnesota Press.

Biron C (2020) No address? Voting while homeless is challenging in US election. Washington: Thomas Reuters Foundation.

Blomley N (2006) Editorial: Homelessness and the delusions of property. Transactions of the Institute of British Geographers 31(1): 3-5.

Byrd J and Rothberg M (2011) Between subalternity and indigeneity. Interventions 13(1): 1-12.

Carraway C (2020) Skint Estate: Notes from the Poverty Line. London: Ebury Press.

Casanova R (as told to S Blackburn) (1996) Each One Teach One: Up and Out of Poverty: Memoirs of a Street Activist. Willimantic: Curbstone Press.

Christensen J (2013) 'Our home, our way of life': Spiritual homelessness and the sociocultural dimensions of Indigenous homelessness in the Northwest Territories (NWT), Canada. Social \& Cultural Geography 14(7): 804-828.

Clayton D (2011) Subaltern space. In: Agnew JA and Livingstone D (eds) Handbook of Geographical Knowledge. London: Sage, pp. 246-260.

Cloke P, Milbourne P, and Widdowfield R (2001) Making the homeless count? Enumerating rough sleepers and the distortion of homelessness. Policy and Politics 29(3): 259-279. 
Coronil F (1994) Listening to the subaltern: The poetics of neocolonial states. Poetics Today 15(4): 643-658.

Craft LJ (1997) Novels of Testimony and Resistance from Central America. Gainesville: University Press of Florida.

de Jong S and Mascat J (2016) Relocating subalternity: Scattered speculations on the conundrum of a concept. Cultural Studies 30(5): 717-729.

Deleuze D and Foucault M (1977) Intellectuals and power. In: Bouchard D (ed) Language, Counter-Memory, Practice. Ithaca: Cornell University Press, pp. 205-217.

Eighner L (2013) Travels with Lizbeth: Three Years on the Road and on the Street. New York: St. Martin's Press.

Escobar A (2003) Displacement, development, and modernity in the Colombian Pacific. International Social Science Journal 55(175): 157-167.

Featherstone D (2013) Black internationalism, subaltern cosmopolitanism, and the spatial politics of antifascism. Annals of the Association of American Geographers 103(6): 1406-1420. Farrugia D and Gerrard J (2016) Academic knowledge and contemporary poverty: The politics of homelessness research. Sociology 50(2): 267-284.

Fitzpatrick S, Pawson H, Bramley G, Wilcox S, Watts B and Wood J (2018) The Homelessness Monitor: England 2018. London: Crisis.

Flynn N (2004) Another Bullshit Night in Suck City. New York: W. W. Norton and Company.

Gilmore L (2001) Limit-cases: Trauma, self-representation, and the jurisdictions of identity. Biography 24(1): 128-139.

Gramsci A (1971) Selections from the Prison Notebooks of Antonio Gramsci. Hoare Q and Nowell-Smith G (trans). New York: International Publishers.

Gramsci A (1991) Selections from the cultural writings. Boelhower B (trans), Forgacs D and Nowell-Smith G (eds). Cambridge: Harvard University Press.

Gray-Garcia L (2006) Criminal of Poverty: Growing Up Homeless in America. San Francisco: City Lights Books.

Green M (2002) Gramsci cannot speak: Presentations and interpretations of Gramsci's concept of the subaltern. Rethinking Marxism 14(3): 1-24.

Guha R (1982) On some aspects of the historiography of colonial India. In: Guha R (ed) Subaltern Studies I: Writings on South Asian History and Society. Delhi: Oxford University Press, pp. 1-7. 
Guha R (1983) The prose of counterinsurgency. In Guha R and Spivak G (eds) Selected Subaltern Studies. Oxford: Oxford University Press, pp. 47-88.

Healy J (2008) The Grass Arena: An Autobiography. London: Penguin.

Hodgetts D, Cullen A and Radley A (2005) Television characterizations of homeless people in the United Kingdom. Analyses of Social Issues and Public Policy 5(1): 29-48.

Jarenski S (2010) Invisibility embraced: The abject as a site of agency in Ellison's Invisible Man Melus 35(4): 85-109.

Jazeel T (2014) Subaltern geographies: Geographical knowledge and postcolonial strategy. Singapore Journal of Tropical Geography 35(1): 88-103.

Jazeel T and Legg S (2019) Subaltern studies, space, and the geographical imagination. In: Jazeel T and Legg S (eds) Subaltern Geographies. Athens: University of Georgia Press, pp. 1-35.

Jazeel T and Legg S (eds) (2019) Subaltern Geographies. Athens: University of Georgia Press.

Jazeel T (2011) The geography of theory: Knowledge, politics, and the postcolonial present. In: Teverson A and Upstone S (eds) Postcolonial Spaces: The Politics of Place in Contemporary Culture. Basingstoke: Palgrave Macmillan, pp. 164-184.

Kawash S (1998) The homeless body. Public Culture 10(2): 319-339.

Klodawsky F, Farrell S and D'aubry T (2002) Images of homelessness in Ottawa: Implications for local politics. The Canadian Geographer/Le Géographe Canadien 46(2): 126-143.

Lancione, M. (2017). The ethnographic novel as activist mode of existence: Translating the field with homeless people and beyond. Social \& Cultural Geography 18(7): 994-1015.

Latin American Subaltern Studies Group (1993) Founding statement. Boundary 20(3): 110-121.

Legg S (2016) Empirical and analytical subaltern space? Ashrams, brothels and trafficking in colonial Delhi. Cultural Studies 30(5): 793-815.

Li V (2009) Necroidealism, or the subaltern's sacrificial death. Interventions 11(3): 275-292.

Lyon-Callo V (2000) Medicalizing homelessness: The production of self-blame and selfgoverning within homeless shelters. Medical Anthropology Quarterly 14(3): 328-345.

Marcuse P (1986) Abandonment, gentrification, and displacement: The linkages in New York City. In: Smith N and Williams P (eds) Gentrification of the City. London: Unwin Hyman, pp. $153-177$. 
May J (2000) Housing histories and homeless careers: A biographical approach. Housing Studies 15 (4):613-38.

McDonough P (1996) Without Keys: My 16 Weeks with the Street People. Melbourne: Terra Sancta Press.

Morris M, Wailey T and Davies A (2017) Dear Garrett: An introduction to the Garrett-Lehmann Letters Chapter. In M Morris, T Wailey and A Davies (eds) Ten Years On The Parish: The Autobiography and Letters of George Garrett Book. Liverpool: Liverpool University Press, pp. 203-211.

Nagar R (2002) Footloose researchers, 'traveling' theories, and the politics of transnational feminist praxis. Gender, Place and Culture 9(2): 179-186.

Narayan U and Harding S (2000) Introduction. In: Narayan U and Harding S (eds) Decentering the Center: Philosophy for a Multicultural, Postcolonial, and Feminist World. Bloomington: Indiana University Press, pp. vii-xvi.

NCH (National Coalition for the Homeless) (2009) Minorities and homelessness. Washington, DC.

NHCHC (National Health Care for the Homeless Council) (2006) The hard, cold facts about the deaths of homeless people. Nashville.

O'Connell D (2003) What happened next? The Guardian.

Peres P (1994) Subaltern spaces in Brazil. Dispositio 19(46): 113-126.

Peters EJ and Robillard V (2009) "Everything you want is there": The place of the reserve in First Nations' homeless mobility. Urban Geography 30(6): 652-680.

Renedo A and Jovchelovitch S (2007) Expert knowledge, cognitive polyphasia and health: A study on social representations of homelessness among professionals working in the voluntary sector in London. Journal of Health Psychology 12(5): 779-790.

Rusenko RM (2020) Homelessness Regulation and Neoliberalism's Imperial Past: The Janus Face of Anti-Homeless Urbanism and Tokyo's Modern Socio-Spatial Development. Antipode 52(6): 1815-1836.

Schmidt K and Robaina IMM (2017) Beyond removal: Critically engaging in research on geographies of homelessness in the city of Rio de Janeiro. Journal of Latin American Geography 16(1): 93-116.

Schneider B, Chamberlain K and Hodgetts D (2010) Representations of homelessness in four Canadian newspapers: Regulation, control, and social order. Journal of Sociology and Social Welfare 37(4): 147-172. 
Schneider B (2012) Sourcing homelessness: How journalists use sources to frame homelessness. Journalism 13(1): 71-86.

Sharp J (2011) Subaltern geopolitics: Introduction. Geoforum 42(3): 271-273.

Sheridan C (2011) London Irish author silenced. The Irish Examiner.

Sircar S (2020). Subalternity. In Kobayashi A (ed) International Encyclopedia of Human Geography, Second Edition. Amsterdam: Elsevier, pp. 111-115.

Sommer D (1999) Proceed with Caution, when Engaged by Minority Writing in the Americas. Cambridge: Harvard University Press.

Spivak GC (1988) Can the subaltern speak? In: Nelson C and Grossberg L (eds) Marxism and Interpretation of Culture. London: Macmillan, pp. 271-313.

Spivak GC (2000) From Haverstock Hill Flat to US classroom, what's left of theory? In: Butler J, Guillory J and Thomas K (eds) What's Left of Theory?: New Work on the Politics of Literary Theory. New York: Routledge, pp. 1-39.

Spivak GC (2005) Scattered speculations on the subaltern and the popular. Postcolonial Studies 8(4): 475-448.

Stabrowski F (2014) New-build gentrification and the everyday displacement of Polish immigrant tenants in Greenpoint, Brooklyn. Antipode 46(3): 794-815.

Stringer L (1998) Grand Central Winter: Stories from the Street. New York: Seven Stories Press.

The Film Archives (2013) Lee Stringer and Kurt Vonnegut on Grand Central Winter: Stories from the Street (1998) [video file]. https://www.youtube.com/watch?v=2gc8MlHsZRY

Tina S and Bolnick J (2000) Living at the Edge of the World: How I Survived in the Tunnels of Grand Central Station. New York: St. Martin's Griffin.

Torck D (2001) Voices of homeless people in street newspapers: A cross-cultural exploration. Discourse and Society 12(3): 371-392.

Varadharajan A (1995) Exotic parodies: Subjectivity in Adorno, Said, and Spivak. Minneapolis: University of Minnesota Press.

Willse C (2015) The Value of Homelessness: Managing Surplus Life in the United States. Minneapolis: University of Minnesota Press.

Wojnarowicz D (1991) Close to the Knives: A Memoir of Disintegration. New York: Vintage Books. 